\title{
Cytochemical bioassays of polypeptide hormones
}

\author{
Lucille Bitensky \\ Division of Cellular Biology and W.H.O. Collaborating Centre for Cytochemical Bioassay, \\ Kennedy Institute of Rheumatology, Bute Gardens, London W6 7DW, U.K.
}

\section{Introduction}

In the early days of endocrinology hormones were recognized, and assayed, by some characteristic biological function. For example, corticotrophin (ACTH) was assayed by the amount of corticosterone which was produced in vivo as a response to the injection of graded amounts of this hormone into rats (Lipscomb \& Nelson, 1962). This was a simple and direct effect of ACTH. Equally, it could be assayed by the depletion in vivo of ascorbate from the adrenal gland (Sayers, Sayers \& Woodbury, 1948). Although there was a clear correlation between the loss of ascorbate from the adrenal and the concentration of ACTH acting on the gland, there was little information relating ascorbate depletion and secretion of corticosterone or cortisol (depending on the animal used in the assay). The obvious physiological effect of ACTH was to produce corticosterone (or cortisol), but the hormone could be assayed with reasonable precision by a secondary, or biochemical, phenomenon which is now recognized as being part of the biochemical mechanisms involved in steroidogenesis (Chayen, Daly, Loveridge \& Bitensky, 1976).

As regards the gonadotrophic hormones, the situation has been at least as complex. For example, a standard method of detecting and assaying LH has been to measure its ability to deplete ascorbate from the ovary, or more particularly, from the ovary of animals induced to superovulate (Parlow, 1961). Equally, FSH has been assayed by the increased ovarian weight it induces (Steelman \& Pohley, 1953). Both these effects are less immediate than is the secretion of corticosterone in response to ACTH, yet both form the bases of reliable bioassays.

The application of physico-chemical analytic methods to the purification of polypeptide hormones made it possible to isolate the hormone. At the same time, the development of radiochemical and immunochemical techniques (e.g. Ekins, 1960; Yalow \& Berson, 1960) opened the way to radioimmunoassay in which the molecular species itself, or specific antigenic determinants, were identified and measured (e.g. Yalow \& Berson, 1960, for insulin; Berson \& Yalow, 1968; Landon \& Greenwood, 1968). These methods did not have to depend on a biological function, whether it was a primary or secondary function; they were able to determine the presence, and concentration, of specific molecules corresponding to that which gave the hormone its biological function. These methods were considerably more sensitive than were the older bioassays and can be considered to be 'analytical' techniques, akin to those of analytical chemistry.

Clearly certain precautions had to be, and were, taken. For example, there was no point in raising an antibody to the $\alpha$-subunit of FSH since that antibody would cross-react with all glycoprotein hormones which have the common subunit. Equally, it was inadvisable to use an antibody to the C-terminal amino acids of ACTH when the biological activity resided in the N-terminal part; the former could give erroneous values for biological activity (as discussed by Besser et al., 1971).

But in spite of all the precautions, some inadequacies of radioimmunoassay techniques had become evident, even as early as 1967 (see WHO Report, 1975). The most fundamental problem, as emphasized by the WHO Expert Committee on Biological Standardization (WHO Report, 1975), was that immunoassays measure a composite of antigenic activity which is not necessarily related to the bioactivity of the hormone. The recent evidence that most polypeptide hormones may occur in various, almost polymeric, forms (e.g. 'big' ACTH; 'big big' gastrin, as discussed by Yalow, 1974), has meant that the mere recognition of a group of antigenic determinants is not synonymous with the identification of the biologically active hormone. Consequently interest has revived in the development of bioassays which depend on the functional capacity of the hormone to produce either its primary physiological function, or at least a biochemical function associated with it. Such bioassays would need to be performed in parallel with the analytical assays (radioimmunoassays) and have at least the same sensitivity as the latter (WHO Report, 1975). 
As experience with radioimmunoassays has grown, so it has become apparent that, for some polypeptide hormones at least, even the sensitivity of these assays is inadequate. For example, the limit of sensitivity of the best radioimmunoassay for thyrotrophin (TSH) is about $1 \mu \mathrm{U} / \mathrm{ml}$, yet it now seems clear that a considerable proportion of the normal human population has circulating levels of less than this amount. It is therefore difficult at present to decide whether low circulating levels of TSH are associated with certain clinical conditions. Moreover, it is unlikely that the present radioimmunoassays for parathyroid hormone (PTH) can measure even high levels of the biologically active hormone (Parsons \& Potts, 1972). Consequently, not only is there a need for functional assays which can be used to confirm that radioimmunoassay is measuring biologically active hormone, but there is a need for increased sensitivity over the best that can be attained by radioimmunoassay. It is because the cytochemical bioassays meet both these requirements that they have been recommended by the WHO Expert Committee on Biological Standardization (WHO Report, 1975).

\section{The development of cytochemistry}

It has been recognized for a long time that the conventional biochemical analysis of a tissue represents only the mean activity or composition present in the various histologically distinct components that comprise that tissue or organ. This is of particular importance in measuring the effect of hormones because it is well known that each hormone attaches only to its specific target cell within the tissue, and may even require that the target cell has reached a suitable stage of differentiation, or 'maturation', before the hormone can assert its function.

Histochemistry and cytochemistry were developed to make it possible to assign biochemical activity to specific cell types within a complex tissue. In general it may be said that histochemistry tended to be concerned predominantly with problems of localization, the exception being the work of Glick (e.g. 1961, 1963; see also review by Symington, 1969). In contrast, cytochemistry has been developed as quantitative cellular biochemistry. The point of similarity is that in histochemistry and cytochemistry the coloured reaction product is precipitated in the cell which produces the reaction. This is in contrast to the techniques normally used in biochemistry in which the reaction product is soluble and is measured in solution. Although this is convenient in that the reaction product can be measured very simply by spectrophotometry, it means that it is impossible to assess the activity of each cell type independently of the others. Yet if the target cells comprise $5 \%$ of the mass of a tissue which shows 100 units of biochemical activity, then even a doubling of activity in the target cells (induced by the hormone) will produce only a $5 \%$ increase overall. To overcome this 'tissue dilution artefact' (Chayen, Jones, Bitensky \& Cunningham, 1961; Jones, Bitensky, Chayen \& Cunningham, 1961), quantitative cytochemistry uses (i) unfixed tissue sections which are free from measurable ice-artefact (Chayen \& Bitensky, 1968; Altman \& Barrnett, 1975) and which are sufficiently thin $(10-20 \mu \mathrm{m})$ for the histology to be ascertained; (ii) reaction media which contain optimal concentrations of reactants, just as in conventional biochemistry; (iii) reactions which produce a precipitated coloured reaction product in the cell which produced this product; and (iv) microdensitometry for measuring the amount of precipitated coloured reaction product in each responding cell, with the same degree of accuracy as that of conventional spectrophotometry (Bitensky, Butcher \& Chayen, 1973).

The techniques of cytochemistry, and their validation, have been discussed by Chayen $\&$ Bitensky (1968), Chayen et al. (1973a,b, 1974) and Bitensky et al. (1973). It has been shown that when these techniques are applied to tissues consisting of a predominantly single-cell type, their results, in absolute terms (e.g. $\mu \mathrm{mol} \mathrm{H}_{2}$ /unit time), agree closely with those obtained by conventional biochemical procedures (e.g. Butcher, 1970; Altman, 1972; Chayen, 1977).

\section{The application of cytochemistry to the assay of hormones}

Considerable advances in our knowledge of the action of hormones have come from the studies of several workers, notably Gaillard (e.g. Gaillard \& Schaberg, 1965) and Fell (e.g. Fell \& Rinaldini, 1965; also see Laznitzki, 1965) who maintained tissues in organ culture and observed the effects of the 
relevant hormones on rates of growth, or other structural features. The cytochemical bioassays represent an extension of these studies in that they use the newer methods of quantitative cytochemistry to measure the biochemical changes induced by the hormone.

The general procedure for the simpler cytochemical bioassays, the cytochemical segment bioassays, is as follows.

\section{Culture}

The relevant organ is removed from a suitable animal, usually a guinea-pig, after death by asphyxiation with nitrogen. It is cut into a number of segments and each of these is maintained separately in Trowell's (1959) non-proliferative maintenance culture for adult tissues. The segment is placed on a de-fatted lens tissue lying on an expanded metal mesh grid table (Text-fig. 1) with the synthetic Trowell's T8 medium only up to the level of the table. In this way the segment is fed with the nutrients, through the lens tissue, but is not immersed in the medium. The table and the vitreosil dish containing the medium are placed in a Perspex culture pot which has a large gas capacity; the gas is usually $95 \% \mathrm{O}_{2} / 5 \% \mathrm{CO}_{2}$. The segment is maintained in vitro in this way at $37^{\circ} \mathrm{C}$ for $5 \mathrm{~h}$.

This procedure has a number of advantages, all of which contribute towards the sensitivity of these assays. Firstly it removes the target cells from the hormonal influence of the animal; the degree of hormonal stimulation which occurred in life, and during the stress of death, will have worn off during the period of culture. Secondly, it allows the cells to recover from the trauma of excision. For example, the relevant cells of the adrenal cortex are unresponsive for the first $3 \mathrm{~h}$ after removal from the animal. Thirdly, this period of culture can be used to allow the cells to take up additional material can which increase the sensitivity of their response to the hormone. For the cytochemical bioassay of ACTH, therefore, which depends on ascorbate depletion, ascorbate $\left(10^{-3} \mathrm{M}\right)$ is added to the T8 medium (Text-fig. 2). Lastly, by taking 6 segments from one animal, the assay becomes a 'within-animal' assay ( 4 segments for the standard calibration graph and 2 for testing the plasma at two different concentrations), thus obviating the 'between-animal' variation which has been a source of imprecision in most bioassays.

\section{Treatment with hormone}

At the end of $5 \mathrm{~h}$ the medium is removed from each segment. For 4 segments it is replaced with fresh medium containing one of a graded series of concentrations of a standard hormone preparation. This provides the standard calibration graph (e.g. Text-fig. 3). The medium of the other 2 segments is replaced with fresh medium containing one of two concentrations of the plasma to be assayed. Because of the sensitivity of these assays, the plasma is usually diluted $1 / 100$ and $1 / 1000$. We therefore have a within-animal assay with two concentrations of the plasma which allows us to test whether the active principle in the plasma produces a response which is parallel to that of the standard preparation. Having two concentrations of the same plasma also acts as a check on the precision of that particular assay; the results, calculated back to the original concentration, should agree to $\pm 15 \%$ if reliance is to be placed on the assay.

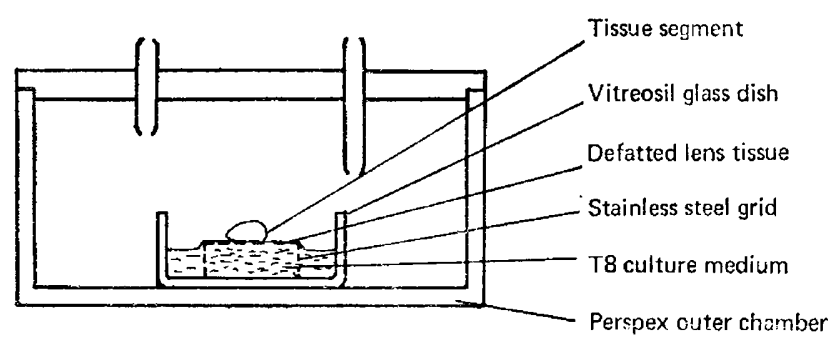

Text-fig. 1. Diagrammatic representation of the adult organ maintenance culture system. 


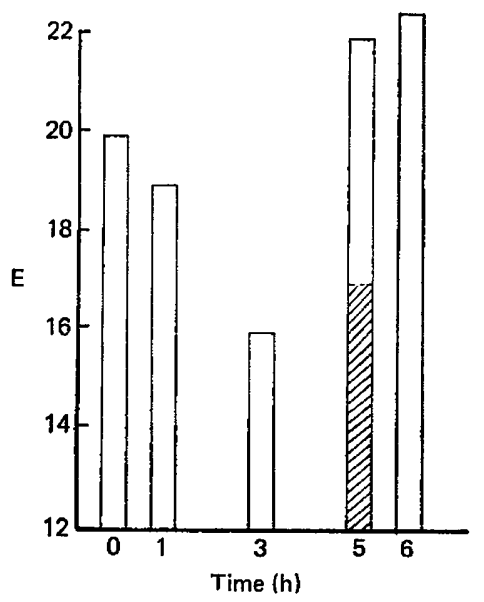

Text-fig. 2. The concentration of ascorbate (E) in the zona reticularis of a guinea-pig during prolonged culture. The ascorbate concentration is replenished only after $5 \mathrm{~h}$. The hatched column shows that there is no recovery of ascorbate in these cells when the segment is cultured without additional ascorbate in the medium.

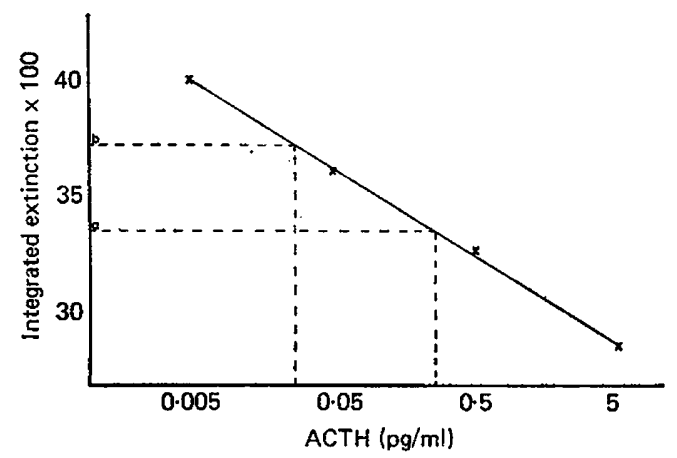

Text-fig. 3. An assay of ACTH in plasma. The crosses show the response (see p. 291) in the cells of the zona reticularis in four segments treated with different concentrations of a standard preparation of ACTH; the concentration of ACTH in the plasma, suitably diluted to (a) 1:100 and (b) 1:1000, is shown by the broken lines: $(\mathrm{a})=26 \mathrm{pg} / \mathrm{ml},(\mathrm{b})=27 \mathrm{pg} / \mathrm{ml}$.

The time of exposure to the hormone is very short to achieve maximal response at these low concentrations (Table 1).

Table 1. Summary of some cytochemical assays for various hormones

\begin{tabular}{llllll}
\hline Hormone & \multicolumn{1}{c}{ Target cells } & Response & $\begin{array}{c}\text { Time to } \\
\text { maximal } \\
\text { response }\end{array}$ & $\begin{array}{c}\text { Limit of } \\
\text { sensitivity }\end{array}$ & Reference \\
\hline ACTH & $\begin{array}{c}\text { Zona reticularis of } \\
\text { adrenal cortex } \\
\text { Theca luteal cells } \\
\text { Thyroid follicle cells }\end{array}$ & Ascorbate depletion & $4 \mathrm{~min}$ & $5 \mathrm{fg} / \mathrm{ml}$ & Chayen et al. (1972) \\
TSH $^{*}$ & $\begin{array}{c}\text { Ascorbate depletion } \\
\text { Change in lysosomal } \\
\text { permeability }\end{array}$ & $\begin{array}{c}4 \mathrm{~min} \\
7 \mathrm{~min}\end{array}$ & $\begin{array}{l}0.005 \mathrm{mU} / \mathrm{ml} \\
10^{-4} \mu \mathrm{U} / \mathrm{ml}\end{array}$ & $\begin{array}{l}\text { Rees } \text { et al. } \text { (1973b) } \\
\text { Bitensky } \text { et al. (1974) }\end{array}$ \\
Gastrin & $\begin{array}{l}\text { Parietal cells of stomach } \\
\text { fundus }\end{array}$ & $\begin{array}{l}\text { Activation of carbonic } \\
\text { anhydrase }\end{array}$ & $5 \mathrm{~min}$ & $0.005 \mathrm{pg} / \mathrm{ml}$ & Loveridge et al. (1974) \\
\hline
\end{tabular}

* Thyroid stimulating antibodies can also be assayed by means of this system; time to achieve maximal response: 30 min (Bitensky et al., 1974; Petersen et al., 1975). 


\section{Cytochemistry}

At the time of maximal response to the hormone, the segments are chilled rapidly to $-70^{\circ} \mathrm{C}$. Later they are sectioned at, for example, $10 \mu \mathrm{m}$ in a cryostat, with a cabinet temperature of $-25^{\circ} \mathrm{C}$ and with the knife cooled to below $-70^{\circ} \mathrm{C}$ by solid $\mathrm{CO}_{2}$. The sections are flash dried off the knife on to a slide taken from the ambient temperature of the laboratory. These are standard methods for quantitative cytochemistry (Chayen et al., 1973a). To achieve constant thickness of sections, it is advisable to use an automatic cutting device, such as is fitted to the Bright FS/CS/LT/M cryostat, because the thickness varies with the speed of cutting (Butcher, 1971). The sections are then tested for the particular biochemical change induced by that particular hormone (see Table 1). Duplicate sections are generally taken from each segment but, for calculating fiducial limits, 5 serial sections are taken from each segment. The cytochemical reaction produces a coloured precipitate in each cell, the amount of colour being quantitatively related to the amount of the biochemical activity present in that cell. Then the amount of colour in 10 cells, or 10 groups of similar cells, in each section is measured by means of a Vickers M85 scanning and integrating microdensitometer. With this instrument the coloured section, preferably labelled by a code number to reduce subjectivity, is first inspected by normal light microscopy. The target cells are identified and a mask is placed on the first of these which is to be measured. The instrument then sends a flying-spot across this mask and measures the absorption present in each region of the mask; it integrates all these readings to give an absorption value for the selected cell, or group of cells. This absorption value can then be converted into units of absolute extinction (or absorptivity) by suitable calibration. Because the flying-spot can be made as small as $\mathbf{0 . 2 5} \mu \mathrm{m}$ in diameter, i.e. equal to the resolution of the light microscope, it avoids the inaccuracies, such as the distributional error, normally inherent in such measurement of a coloured precipitate (as discussed by Bitensky et al., 1973; Chayen, 1977).

The use of a suitable microdensitometer also increases the sensitivity inherent in the cytochemical bioassays. Firstly, it avoids the tissue dilution artefact discussed previously. Secondly, because of its construction, it can measure the extinction of a chromophore in a single cell, whereas conventional biochemistry requires about $10^{6}$ cells. Thus on this count alone, it improves sensitivity by a factor of $10^{6}$.

\section{The cytochemical section bioassays}

The cytochemical segment assays require not less than 6 segments of the target tissue to make each assay a 'within-animal' assay and so avoid the considerable 'between-animal' variation that has detracted from reproducibility and sensitivity of in-vivo bioassays. It is, however, difficult to obtain more than 6 segments of thyroid or adrenal cortical tissue from any one guinea-pig. Consequently the assay of a single plasma sample, at two dilutions, requires one animal, and six measurements (see Text-fig. 3). The next plasma sample will also require a new calibration graph for the tissue of the second animal, in the tissue of which the sample is to be assayed. This is too laborious and too costly a process for routine assaying of many samples. Consequently, modifications in which the cells in sections of the target tissue are made to respond to the hormone have been developed for the cytochemical bioassay of ACTH (Alaghband-Zadeh, Daly, Bitensky \& Chayen, 1974; AlaghbandZadeh, 1974) and gastrin (Hoile \& Loveridge, 1976).

In the former, the adrenal tissue is maintained in vitro for $5 \mathrm{~h}$, as in the segment assay. It is then stimulated by a low concentration $(0.5 \mathrm{fg} / \mathrm{ml})$ of the hormone, the effect of which is unmeasurable by these assays, but which appears to improve the sensitivity of the subsequent response. The tissue is then chilled, sectioned at $20 \mu \mathrm{m}$ (greater than the largest dimension of the cells of the zona reticularis) and the sections, mounted back-to-back in duplicate, are exposed to the action of the hormone. The medium used for this exposure contains a colloid stabilizer to protect the unfixed sections which would otherwise disintegrate in a buffer solution at pH 7.6 (see Altman \& Chayen, 1965). The response of the sections to ACTH is as sensitive as in the segment assay but is considerably more rapid, maximal response occurring in $60 \mathrm{sec}$. After this time all the sections are transferred simultaneously to the cytochemical reaction medium for testing for ascorbate, and the reaction is measured as for the 
segment assay. By means of simple apparatus (Plate 1) 8 sections (i.e. four groups in duplicate) can be used for measuring the response of the tissue to four graded concentrations of the hormone $(5 \mathrm{fg} / \mathrm{ml}$ to $5 \mathrm{pg} / \mathrm{ml}$ ) while the other compartments of the apparatus can be used for many plasma samples, each at two dilutions. It is helpful also to include a 'quality control' sample. All these samples can be tested simultaneously on serial sections of the same adrenal gland of one guinea-pig. The 'throughput' of this section-assay is about 40 assays per week per worker.

\section{Validity of the cytochemical bioassays}

For brevity the forms of validation used for the assay of ACTH will be taken as a model for all the cytochemical bioassays.

Reproducibility. Variation between segments treated separately with the same concentration of hormone was $< \pm 4 \%$; the coefficient of variation for results from 5 sections cut from 5 segments treated with different concentrations of the hormone was $<5 \%$ for each concentration tested. The same two plasma samples tested on consecutive days gave results of (a) 14.7 and $14 \cdot 7$, and (b) 236 and $250 \mathrm{pg} / \mathrm{ml}$ (Chayen, Loveridge \& Daly, 1972).

Sensitivity. The lowest concentration of the hormone which consistently gives readings different from zero concentration, is $5 \mathrm{fg} / \mathrm{ml}\left(5 \times 10^{-15} \mathrm{~g} / \mathrm{ml}\right)$. In human plasma, after suppression with cortisol, Rees et al. (1973a) recorded $34 \mathrm{fg} / \mathrm{ml}$; Holdaway, Rees, Ratcliffe, Besser \& Kramer (1974) reported residual values of as low as $10 \mathrm{fg} / \mathrm{ml}$ in human plasma treated with an antibody to ACTH.

Precision. For a series of 10 assays, Buckingham (1974) reported that the index of precision was $0.076 \pm 0.002$; the fiducial limits were $86-115 \%$ to $98-101 \%$ (Daly, Loveridge, Bitensky \& Chayen, 1974). The recovery of added hormone was 101-102\% (Alaghband-Zadeh et al., 1974).

Specificity. Various other hormones, such as LH (which causes ascorbate depletion in the ovary but not in the adrenal), prolactin, the biologically inactive C-terminal ACTH peptide $\alpha^{18-39}$ showed virtually no cross-reaction; $\beta$ MSH, which shares some of the $\mathrm{N}$-terminal amino acids, gave $<0.01 \%$ cross-reaction (Holdaway et al., 1974). The addition of a specific antibody to plasma containing ACTH produced $90 \%$ loss of the assayable activity (Holdaway et al., 1974).

Comparison with radioimmunoassay. Various concentrations of the hormone, added to pooled plasma and assayed by the Lipscomb-Nelson bioassay, by radioimmunoassay and by the cytochemical bioassay, gave statistically identical values at all concentrations at which the respective assays were capable of measurement (Rees et al., 1973a). In more dynamic situations, in which the hormone levels rise rapidly and fall quickly, as in the insulin hypoglycaemia test in vivo, differences between radioimmunoassay and the cytochemical bioassay became apparent during the period when the levels were falling (Fleisher, Glass, Bitensky, Chayen \& Daly, 1974). This would reflect the longer half-life of the hormone, as measured by the radioimmunoassay which was still detecting biologically inactive fragments (Besser et al., 1971).

\section{Advantages of the sensitivity of these assays}

For some hormones, the increased sensitivity of the assays allows the low, but normal, circulating levels in man to be determined for the first time, e.g. TSH (Petersen, Smith \& Hall, 1975). The recent studies of Chambers, Zanelli, Parsons \& Chayen (1976) on parathyroid hormone could lead to determinations of the normal circulating levels of the biologically active form of this hormone.

In general, however, the increased sensitivity afforded by the cytochemical bioassays is useful in two situations: (a) when there are very low levels of the hormone, as in hypopituitarism (Holdaway, Rees \& Landon, 1973) or (b) when very little blood can be taken safely. Holdaway et al. (1973) used this form of assay to determine the level of ACTH in samples obtained by a heel-prick from neonates. Only small samples can be taken when studying the episodic secretion of hormones (Gallagher et al., 1973), many samples being required over a period of some hours. About $1 \mathrm{ml}$ blood is ample for samples which are to be measured at $1 / 100$ and and 1/1000 dilution. Similar considerations pertain to sequential sampling from small laboratory animals. 


\section{PLATE 1}

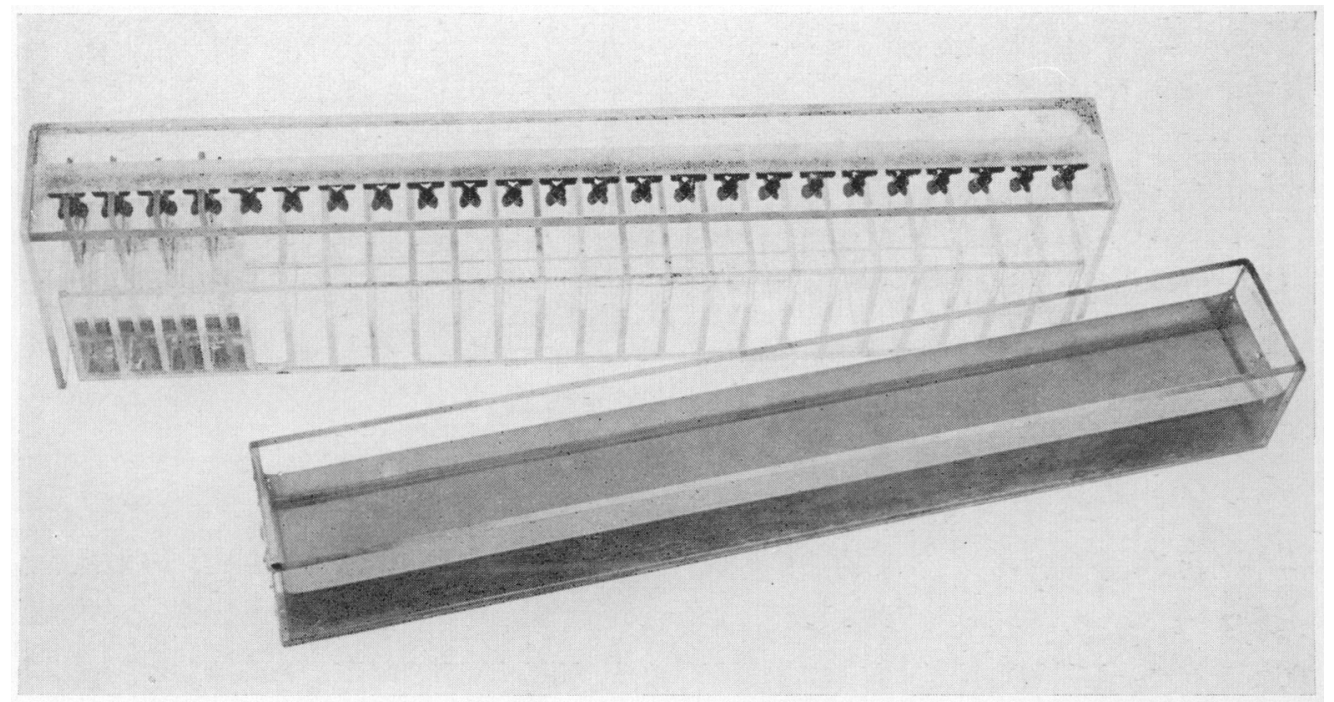

The apparatus used for the section assay of ACTH. In the background is the vessel used for treating the sections, which are back-to-back. In the foreground is the trough containing the cytochemical reagents for testing for ascorbate. At the end of $1 \mathrm{~min}$ the lid holding the sections is transferred to the cytochemical reaction trough. 


\section{References}

Alaghband-Zndeh, J. (1974) Development of a section-bioassay for the routine assay of corticotrophin. Ann. clin. Biochem. 11, 43-48.

Alaghband-Zadeh, J., Daly, J.R., Bitensky, L. \& Chayen, J. (1974) The cytochemical section assay for corticotrophin. Clin. Endocr. 3, 319-327.

Altman, F.P. (1972) Quantitative dehydrogenase histochemistry with special reference to the pentose shunt dehydrogenases. Progr. Histochem. Cytochem. 4, 225-273.

Altman, F.P. \& BarRnetT, R.J. (1975) The ultrastructural localisation of enzyme activity in unfixed sections. Histochemistry 44, 179-183.

Altman, F.P. \& Chayen, J. (1965) The retention of nitrogenous material in unfixed sections during incubation for histochemical demonstration of enzymes. Nature, Lond. 207, 1205-1206.

Berson, S.A. \& Yalow, R.S. (1968) Radioimmunoassay of ACTH in plasma $J$. clin. Invest. 47, 27252751.

Besser, G.M., ORth, D.N., Nicholson, W.E., Byyny, R.L., ABE, K. \& Woodham, J. (1971) Dissociation of the disappearance of bioactive and immunoreactive ACTH from plasma in man. J. clin. Endocr. Metab. 32, 595-603.

Bitensky, L., Butcher, R.G. \& Chayen, J. (1973) Quantitative cytochemistry in the study of lysosomal function. In Lysosomes in Biology and Pathology, Vol. 3, pp. 465-510. Ed. J. T. Dingle. North-Holland, Amsterdam.

Bitensky, L., Alaghband-Zadeh, J. \& Chayen, J. (1974) Studies on thyroid stimulating hormone and the long acting thyroid stimulating hormone. Clin. Endocr. 3, 363-374.

BUCKINGHAM, J. (1974) The influence of natural and synthetic corticosteroids on circulating and pituitary corticotrophin in the rat. Ph.D. thesis, University of London.

Butcher, R.G. (1970) Studies on succinate oxidation. I. The use of intact tissue sections. Expl Cell Res. 60, 54-60.

BUTCHER R.G. (1971) The chemical determination of section thickness. Histochemie 28, 131-136.

Chambers, D.J., Zanelli, J.M., Parsons, J.A. \& ChAYEN J. (1976) Cytochemical responses of the guinea-pig kidney cortex to low concentrations of bovine parathyroid hormone $(0 \cdot 001-0 \cdot 1 \mathrm{pg} / \mathrm{ml}) . J$. Endocr. 71, 87P.

Chayen, J. (1977) Microdensitometry. In Biochemical Mechanisms of Liver Injury. Ed. T.F. Slater. Academic Press, New York.

Chayen, J. \& Bitensky, L. (1968) Multiphase chemistry of cell injury. In The Biological Basis of Medicine, Vol. I, pp. 337-368. Eds E. E. Bittar \& N. Bittar. Academic Press, London.

Chayen, J., Jones, G.R.N., Bitensky, L. \& CunningHAM, G.J. (1961) Histological variation as a source of biochemical error. Biochem J. 79, 34P.

Chayen, J., Loveridge, N. \& Daly, J.R. (1972) A sensitive bioassay for adrenocorticotrophic hormone in human plasma. Clin. Endocr. 1, 219-233.

Chayen, J., Bitensky, L. \& Butcher, R.G. (1973a) Practical Histochemistry. Wiley, London.
Chayen, J., Altman, F.P. \& Burcher, R.G. (1973b) The effect of certain drugs on the production and possible utilization of reducing equivalents outside the mitochondria. In Fundamentals of Cell Pharmacology, pp. 196-230. Ed. S. Dikstein. Thomas, Illinois.

Chayen, J., Bitensky, L., Butcher, R.G. \& Altman F.P. (1974) Cellular biochemical assessment of steroid activity. Adv. Steroid Biochem. Pharmac. 4, $1-60$.

Chayen, J., Daly, J.R., Loveridge, N. \& Bitensky, L. (1976) The cytochemical bioassay of hormones. Recent Prog. Horm. Res. 32, 33-79.

Daly, J.R., Loveridge, N., Bitensky, L. \& Chayen, J. (1974) The cytochemical bioassay of corticotrophin. Clin. Endocr. 3, 311-318.

EkINS, R.P. (1960) The estimation of thyroxine in human plasma by an electrophoretic technique. Clinica chim. Acta 5, 453-459.

Fell, H.B. \& RINALDiNI, L.M. (1965) The effects of vitamins $\mathrm{A}$ and $\mathrm{C}$ on cells and tissues. In Cells and Tissues in Culture, Vol. 1, pp. 659-691. Ed. E. N. Willmer. Academic Press, New York.

Fleisher, M.R., Glass, D., Bitensky, L., Chayen, J. \& DALY, J.R. (1974) Plasma corticotrophin levels during insulin-hypoglycaemia : comparison of radioimmunoassay and cytochemical bioassay. Clin. Endocr. 3, 203-208.

Gaillard, P.J. \& SchaberG, A. (1965) Endocrine glands. In Cells and Tissues in Culture, Vol. 2, pp. 631-696. Ed E. N. Willmer. Academic Press, New York.

Gallagher, T.F., Yoshida, K., Ropfwarg, H.D., Fukushima, D.K., WeitzmanN, E.D. \& Hellman, L. (1973) ACTH and cortisol secretory patterns in man. J. clin. Endocr. Metab. 36, 1058-1068.

GLICK, D. (1961, 1963) Quantitative Chemical Techniques of Histo- and Cytochemistry, Vols I and II. Wiley, New York.

Holle, R.W. \& Loveridge, N. (1976) Preliminary studies on a cytochemical section bioassay for gastrin. $J$. Endocr. 71, 87-88P.

Holdaway, I.M., ReEs, L.H. \& Landon, J. (1973) Circulating corticotrophin levels in severe hypopituitarism and in the neonate Lancet ii, 1170-1172.

Holdaway, I.M., Rees, L.H., Ratcliffe, J.G., BesSER, G.M. \& KRAMER, R. (1974) Validation of the redox cytochemical assay for corticotrophin. Clin. Endocr. 3, 329-334.

Jones, G.R.N., Bitensky, L., Chayen, J. \& CunningHAM G.J. (1961) Tissue dilution artifact: a reinterpretation of variations in levels of succinic dehydrogenase during chemical carcinogenesis. Nature, Lond. 191, 1203.

LANDON, J. \& GReENwood, F.C. (1968) Homologous radioimmunoassay for plasma-levels of corticotrophin in man. Lancet i, 273-276.

LAZNITZKI, I. (1965) The action of hormones on cell and organ cultures. In Cells and Tissues in Culture, Vol. 1, pp. 591-658. Ed. E. N. Willmer. Academic Press, New York.

LipsCOMB, H.S. \& Nelson D.H. (1962) A sensitive biological assay for ACTH. Endocrinology 71, 13-23. 
LOVERIDGe, N., BloOM, S.R., WelbouRN, R.B. \& CHAYeN, J. (1974) Quantitative cytochemical estimation of the effect of pentagastrin (0.005-5 $\mathrm{pg} / \mathrm{ml}$ ) and of plasma gastrin on the guinea-pig fundus in vitro. Clin. Endocr. 3, 389-396.

PARLOW, A.F. (1961) Bio-assay of pituitary luteinizing hormone by depletion of ovarian ascorbic acid. In Human Pituitary Gonadotrophins, pp. 300-310. Ed. A. Albert. Thomas, Illinois.

Parsons, J.A. \& Potts, J.T. (1972) Physiology and chemistry of parathyroid hormone. In Calcium Metabolism and Bone Disease, pp. 33-78. Ed. I. MacIntyre. (Clinics in Endocrinology and Metabolism, Vol. 1, No. 1.) W. B. Saunders, London.

Petersen, V., Smith, B.R. \& Hall, R. (1975) A study of thyroid stimulating activity in human serum with the highly sensitive cytochemical bioassay. J. clin. Endocr. Metab. 41, 199-202.

ReEs, L.H., RATCliffe, J.G., Besser, G.M., KRAMER, R., LANDON, J. \& CHAYEN, J. (1973a) Comparison of the redox assay for ACTH with previous assays. Nature, New Biol. 241, 84-85.
Rees, L.H., Holdaway, I.M., Kramer, R., McNeilly, A.S. \& CHARD, T. (1973b) New bioassay for luteinizing hormone. Nature, New Biol. 244, 232-234.

SAyers, M.A., SAYers, G. \& WoOdBURY, L.A. (1948) The assay of adrenocorticotrophic hormone by the adrenal ascorbic acid-depletion method. Endocrinology 42, 379-393.

Steelman, S.L. \& Pohley, F.M. (1953) Assay of follicle stimulating hormone based on the augmentation with human chorionic gonadotrophin. Endocrinology 53, 604-616.

Symington T. (1969) Functional Pathology of the Human Adrenal Gland. Livingstone, Edinburgh.

Trowell, O.A. (1959) The culture of mature organs in a synthetic medium. Expl Cell Res. 16, 118-147.

WHO REPORT (1975) World Health Organisation, Tech. Rep. Ser. No. 565.

YaLOw, R.S. (1974) Heterogeneity of peptide hormones. Recent Prog. Horm. Res. 30, 597-633.

YALOW, R.S. \& BERSON, S.A. (1960) Immunoassay of endogenous plasma insulin in man. J. clin. Invest. 39, 1157-1175. 